\title{
INTERACTION OF EU ETS ALLOWANCES AND ENERGY PRICES: EVIDENCE FROM THE CZECH REPUBLIC ${ }^{1}$
}

\author{
Barbora Vondrušková, Ingeborg Němcová, Jiří Horák
}

\section{Klíčová slova:}

EU ETS, klimaticko-energetický balíček, ceny elektřiny, ceny uhlí, ceny emisních povolenek, změna klimatu, strukturovaný kointegrovaný VAR model, Dickey-Fullerův test, HodrickPrescottův filtr

\section{Key words:}

EU ETS, climate and energy package, energy prices, coal prices, prices of emission allowances, climate change, structural cointegrated VAR model, Dickey-Fuller test, HodrickPrescott filter

\begin{abstract}
Abstrakt
Tento článek úzce vychází z jedné z primárních výzev Evropské unie, kterou je globální, ekonomicky a environmentálně udržitelný rozvoj, v současnosti ohrožovaný změnou klimatu způsobenou rostoucí koncentrací skleníkových plynů v atmosféře. Nejméně nákladnou a vysoce transparentní variantu politiky na redukci skleníkových plynů představují tržní instrumenty (obchodování s emisemi, zdanění uhlíku, atd). První pokus o koordinované mezinárodní úsilí v této oblasti znamenal tzv. Kjótský protokol s platností do roku 2012, nyní se intenzivně vyjednává o jeho nástupci. EU svou představu o post-kjótském režimu promítla do tzv. klimaticko-energetického balíčku, schváleného Evropskou radou v prosinci 2008. Ústřední roli zde hraje revidovaný systém EU ETS jako klíčový nástroj mitigace skleníkových plynů. Autoři prŕspěvku se proto pokusí interpretovat tento závazek a jeho dopady na ceny elektřiny $\mathrm{v}$ ČR, tj. kvalifikovaně odhadnout náklady a určit hlavní ekonomické dopady.
\end{abstract}

\begin{abstract}
This article follows closely one of the principal challenges of the European Union - global, economic and environmentally sustainable development. This development is currently endangered by climate change which is being caused by increasing concentration of greenhouse gases in the atmosphere. At this moment, market instruments (emissions allowances trading, carbon taxation, etc.) represent such a green house gases reduction policy, attributed with the lowest cost level and high transparency. First attempt on coordinated international effort within this domain was the Kyoto protocol valid until 2012 - currently there are intensive negotiations being hold at different levels about its successor. The European Union has projected its vision on post-Kyoto functioning into so called climate and energy package, adopted by the European Council in December 2008. Main part is being represented by revised EU ETS system, playing the role of the main instrument of greenhouse gases mitigation. Writers of this article aim to interpret this engagement and its impacts on energy prices in Czech Republic, respectively estimate expertly costs of that instrument and describe crucial economic consequences.
\end{abstract}

\footnotetext{
${ }^{1}$ This contribution was written as part of the solution of the research project of the IGA „Energetika a evropský systém obchodování s emisemi “ no. F2/37/2010.
} 


\section{Introduction}

Climate change is quite generally perceived as one of greatest threats that our planet together with all human beings will have to face in future. Or even now. It is said and has been proven that if the Earth's temperature rises by more than $2{ }^{\circ} \mathrm{C}$ above pre-industrial levels, climate change is likely to become irreversible and the long-term consequences could be immense (for details see e.g. Stern, 2006). On the other hand, if one takes an early action, climate change might be rather a challenge than a threat. It may be the impulse needed in order to turn the existing economic order on a more sustainable, low-carbon and energy- efficient path.

The European Union tries hard to approach the climate change as a challenge and incorporate it within its economic policies. Clear evidence of that fact is the introduction of a single, EU wide market tool to curb the greenhouse gases (GHG) emissions in the EU. That tool is known under the abbreviation ETS, meaning Emission Trading Scheme (ETS). It came into operation in January 2005 as the largest multi-country, multi-sector GHG trading system world-wide and with a fourteen-month delay followed its founder ${ }^{2}$. At he beginning the tool was considered to help the European Union to meet its Kyoto commitment but in the course of time it has developed into a more ambitious system enabling the European Union to tame its emissions for at least the next decade.

The system is a kind of cap-and-trade system i.e. is based on a given cap on emissions and trade in emission allowances and thus gives value to reducing $\mathrm{CO}_{2}$ emissions. How does that work in practice? All Member States set an overall emissions cap for industry, and issue allowances (i.e. rights to emit one tonne of $\mathrm{CO} 2$ ) equal to that cap. Their facilities subject to the cap are required to surrender an allowance for every tonne of $\mathrm{CO} 2$ they emit. The system regulates the carbon dioxide emissions of approximately 15,000 companies or facilities in the oil and gas, power generation, pulp and paper, cement and glass, and steel sectors across the EU. These installations are allocated tradable emissions allowances each year. Companies whose emissions exceed their store of allowances will face large penalties. In addition to paying the penalties, companies are still required to submit the missing allowances in the following year. Instead of reducing its own emissions, a company can meet its target by purchasing allowances from another company who has a surplus due to an emissions reduction project, too. This creates an incentive for those companies who can reduce emissions at lower cost than the actual or anticipated market price of allowances, and hence helps lower the overall economic cost of emissions reductions. The total number of allowances under the cap will be reduced annually, thus continually cutting down emissions ${ }^{3}$.

A key achievement is the ability of the system to put a price on carbon. Like any market, the key to pricing is scarcity, and the price depends on both the stringency of a cap (the absolute quantity of allowances available), the demand for allowances and expectations about the future. The most fundamental difference of emissions trading from any normal market is that the amount available depends directly on government decisions about allocations; and expectations about the future are largely expectations about future emission targets (Grubb, Neuhoff 2006). The new regulatory scheme is deemed to have serious implications for European business and may transform the way business is done in the power and heat sector as well as in other relevant industries. That is why the authors decided to try to deal with the issues, however, due to clear limits on the data availability they will centre their attention to the case of the Czech Republic only.

\footnotetext{
${ }^{2}$ The scheme is based on Directive 2003/87/EC of the European Parliament and of the Council of 13 October 2003 establishing a scheme for greenhouse gas emission allowance trading within the Community and amending Council Directive 96/61/EC, which entered into force on 25 October 2003.

${ }^{3}$ A popular description of the ETS functioning available at e.g.: http://www.vertisfinance.com
} 
The authors consider this paper a theoretic exercise enabling them to explore the possibility to build a simple model the aim of which is to draw relevant conclusions on the impacts of the introduction of the ETS system in the Czech Republic. The model should actually describe, through calculating the change in electric prises, the impact of the ETS primarily on power sectors and consequently on the other sectors covered in the ETS.

The depth of the analysis within the paper is given by the following assumptions: i) the paper is just the first from the series of 3 papers dealing with the topic; ii) the authors intend to introduce own model capable of catching the trend of the introduction of the ETS at the very first stage when allowances were allocated for free and at sufficient amount; iii) the argument of a sufficient amount of allowances for free was at least the case of the Czech Republic, a region examined within the paper; iv) the authors were able to gather a majority of the reliable data and build relevant time series on the basis of the information provided from the stakeholders (namely Czech biggest power generator ČEZ and specialised environmental commodity traders). Speaking about the issue of data and its gathering, one needs to be aware of specific conditions in the chosen region, namely the transformation and privatization of industries, short period of „market based“ prices of electric energy (as from the March, 5, 2007 the Power Exchange Central Europe was launched) etc that can seriously influence the results of the model and their interpretations.

\section{Modelling exercise}

\subsection{The model}

For the purpose of describing the dependence between prices of electricity and emission permits, we establish a structural cointegrated VAR model. To start with, in the commonly used classical VAR approach proposed by Sims (1980), every endogenous variable in the system is treated as a function of lagged values of all of the endogenous variables in the system, i.e. as:

$$
y_{t}=A_{1} y_{t-1}+A_{2} y_{t-2} \ldots+A_{p} y_{t-p}+e_{t}
$$

where $y_{t}$ is a vector of a given number of endogenous variables, $A_{l}, \ldots, A_{p}$ are coefficient matrices to be estimated and $e_{t}$ the vector of error terms. However, error terms in this VAR form are usually correlated, ${ }^{4}$ which consequently presents a problem in recovering of the underlying structural disturbances from the VAR, especially when the variance/covariance matrix contains high values. More specifically, shocks to the error terms may then be interpreted as having common component which cannot be associated with a specific variable.

This problem can be solved by imposing certain identification restrictions so that a given shock can then be fully attributed to a particular variable. In a traditional approach, Cholesky decomposition method is proposed, which is based on recursive structure of restrictions. This method implies that the first variable responds only to its own exogenous shocks, the second variable to the first variable's shocks and its owns etc. However, in this case, the choice of the ordering of the variables has a vital effect on the results and the interpretation by itself also may not be necessarily straightforward.

For the purpose of this modelling exercise, we rather use the structural VAR technique as a basis, where the restrictions in principle should be guided by theoretical reasoning. A structural VAR can be written in this form:

$$
B_{0} y_{t}=B_{1} y_{t-1}+B_{2} y_{t-2} \ldots+B_{p} y_{t-p}+\varepsilon_{t}
$$

\footnotetext{
${ }^{4}$ They are uncorrelated only in the special case when there are no contemporaneous effects between endogenous variables.
} 
Furthermore, if $n$ is the number of variables, one has to impose $n^{*}(n-1) / 2$ on the matrix $B_{0}$ to fully identify the system (considering only the short-run restrictions).

However, price variables, such as those we examine, often exhibit dynamic behaviour which is consistent with non-stationary, I(1) processes. In this respect, using I(1) variables in a VAR model would likely bring spurious regression problems. A widely used approach is to use first differencing to obtain stationary I(0) processes; however, valuable information about long-run cointegrating relations is deleted by this procedure. Nevertheless, if all variables are I(1) processes and are cointegrated at the same time, a different approach may be used. This is commonly referred to as cointegrated VAR (CVAR) model or as vector error correction model (VECM), see Johansen (1996).

Given the underlying behaviour of variables we are investigating and the need for a sound interpretability of the results implying the need for a structural model, we therefore use the structural vector error correction model as follows:

$$
B_{0} \Delta y_{t}=\Psi y_{t-1}+\Lambda_{1} \Delta y_{t-1}+\Lambda_{2} \Delta y_{t-2} \ldots+\Lambda_{p-1} \Delta y_{t-p+1}+C d_{t}+\varepsilon_{t}
$$

It can be rewritten to its reduced form:

$$
\Delta y_{t}=\alpha \beta^{\prime} y_{t-1}+\Gamma_{1} \Delta y_{t-1}+\Gamma_{2} \Delta y_{t-2} \ldots+\Gamma_{p-1} \Delta y_{t-p+1}+D d_{t}+e_{t}
$$

Where $y_{t}$ is a vector of endogenous variables, $\alpha$ a vector of parameters measuring speed at which the variables approach the long-run equilibrium, $\beta$ ' a vector of estimates for the long run cointegrated relationship between the variables, $\Gamma_{p}$ 's matrices of parameters for endogenous variables of a given lag, $d$ a vector of exogenous variables, i.e. in our case seasonal dummy variables and $D$ a matrix of parameters associated with these exogenous variables.

The interpretation of equation (4) is simply that $\Delta y_{t}$ can be explained by the error correction term $\alpha \beta^{\prime} y_{t-1}$ and by lagged $\Delta y_{t}$ up to a chosen level, while using seasonal adjustment. Note that $y_{t-1}$ can be explained as equilibrium error that occurred in the previous period: if it is non-zero, the model is out of equilibrium and vice versa.

\subsection{The data}

For our modelling requirements, we use three variables that we consider a priori as endogenous (all in EUR): one year forward prices of Czech electricity, one year forward prices of ARA coal (using daily USD/EUR exchange rate), and emission allowance prices. The rationale for choosing forward, rather than spot prices, is firstly that year forwards are not affected by short-term demand fluctuations and secondly that the share of electricity denominated in spot contracts is comparatively low at the Czech market. The underlying daily data for all three variables was transformed to monthly basis using simple arithmetical average.

However, it should be stressed that for determining of the relationships between these variables, the length of the time series is quite far from being ideal. Specifically, energy has been traded on the energy exchange since August 2007 and for each of the preceding years, electricity prices were set on administrative basis. To prolong the time series (and at the same time assuming that market forces were at least partially playing their role in the interdependence between these three variables), rearward data for additional months until January 2007 were obtained using Hodrick-Prescott filter. To avoid poor performance at ends associated with this filter, a new HP-filtered auxiliary time series running from January 2005 
to March 2010 was constructed (with $\lambda=400$, using both administrative and market prices on daily basis) and the resulting period from January to July 2007 was then appended to the original market-driven time series.

Finally, we add seasonal monthly dummies to capture seasonality in each of these variables, which can be potentially detrimental especially while evaluating energy related prices. The final data used in the model runs from January 2007 to March 2010. All calculations were undertaken using the software JMulTi and EViews.

\subsection{Initial univariate and multivariate tests}

As a first step before modelling the data, a visual inspection of the time series is shown in Figure 1. For a better overview, the data has been scaled so that the respective means are equal to 100. Coal and energy prices seem to be closely related, as well as emission allowance prices, though to a lesser extent.

Figure 1: Scaled data for electricity, emission permit and coal prices

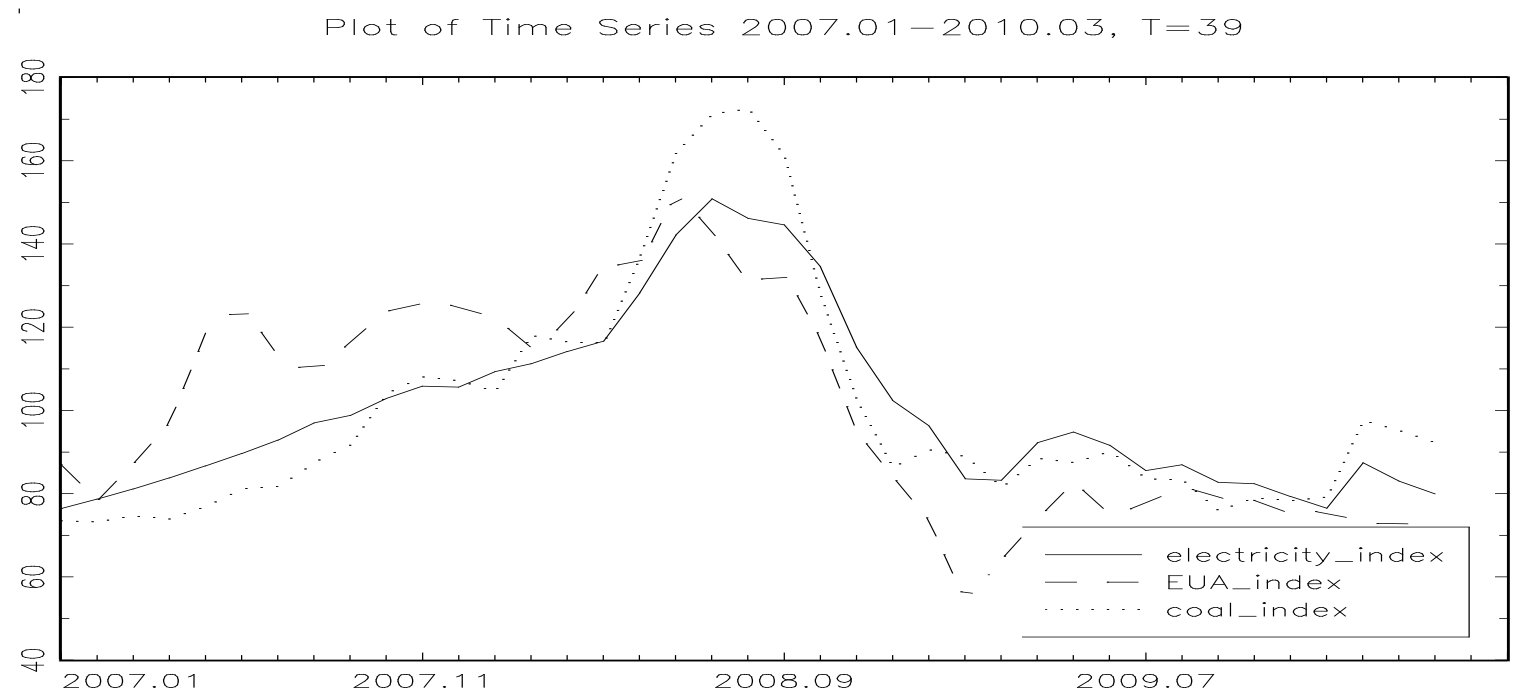

In case of all three series, augmented Dickey-Fuller (ADF) tests fail to reject the null hypothesis of unit root on levels, whereas differences appear to be stationary, so that the exante hypothesis of non-stationarity of price level time series seems to be plausible. The next step is to evaluate cointegration rank in order to confirm that the proposed VECM approach can be applied; for this, we use the trace test as introduced in Johansen (1991).

While assessing the cointegration relationships for possible lags up to level 6 (with or without trend in VAR), one notable feature are quite strong seasonal effects; without seasonal dummies, the trace test indicates no cointegration up to level 4 (without trend in VAR). However, it should be noted that inclusion of exogenous variables into the test, i.e. also seasonal dummies, makes the interpretation of critical values rather difficult. Nevertheless, adjusting for seasonality greatly increases the significance of cointegration relation, all of the examined cases then indicate at least one cointegrating equation (see Table 2 for test statistics of the final model).

For the sake of sound interpretability of the results and greatest parsimony possible, we have chosen the setup with one/two lags and without trend term in VAR, that was not found statistically significant. Moreover, due to a rather small number of observations, models with 
larger number of lags are starting to exhibit unstable behaviour which interpretation would be difficult.

\subsection{Short run dynamics}

After determining the long-run cointegrating relations, the second step will be to examine how the variables behave in short term. As stated in earlier sections, the model in (3) without sufficient restrictions does not provide any information about short-term dynamics, including matrices $B_{0}, A_{p}$, or determining how fast the particular variable approaches the equilibrium which is described by the term $\alpha$ in model (4).

Therefore, we need to impose $n *(n-1) / 2$ restrictions in total, which should be in principle guided by economic theory (in our setup 3 restrictions). We decided not to interfere with the long run determinants of the variables and therefore we chose only to apply restrictions on contemporaneous behaviour of the variables. For this purpose, in order to identify the matrix $B_{0}$ in model (3), the first two restrictions were set so that price of emission permits does not contemporaneously affect coal price and vice versa. The third restriction abandons instantaneous response of the electricity price with respect to emission permit price, therefore assuming adaptive behaviour in this respect.

For determining how a particular shock to a given variable propagates through the model, we utilized the commonly used impulse response function, measuring dynamic response of electricity price to 1 EUR increase of emission permits and coal, respectively. To calculate confidence intervals, we use $95 \%$ Hall percentile with 500 bootstrap replications.

\section{The results}

The results of long-term cointegration estimates are reported in Table 1. All coefficients are statistically significant, which implies that both price of emission permits and coal are crucial to define the level to which electricity price is attracted in the long term. We can also see that all estimates have expected signs. The coefficients themselves can be interpreted as price elasticities, implying that a $1 \%$ increase in price of emission permit price would be, in equilibrium, associated with an $1.2 \% / 0.83 \%$ increase in electricity price. Similarly, an increase in coal prices by $1 \%$ in equilibrium would raise electricity price by $0.17 \% / 0.43 \%$.

Table 1: Cointegrating vector estimates (model with 1 lag)

\begin{tabular}{|lcccc|}
\hline & $1 p_{\text {electricity }}$ & $-1.201 p_{\text {EUA }}$ & $-0.172 p_{\text {coal }}$ & -20.958 \\
p-value & {$[\ldots]$} & {$[0.000]$} & {$[0.019]$} & {$[0.000]$} \\
t-value & $\{\ldots\}$ & $\{-3.518\}$ & $\{-2.355\}$ & $\{-4.704\}$ \\
\hline
\end{tabular}

Table 1: Cointegrating vector estimates (model with 2 lags)

\begin{tabular}{|lccc|}
\hline & $1 p_{\text {electricity }}$ & $-0.831 p_{\text {EUA }}$ & $-0.433 p_{\text {coal }}$ \\
p-value & {$[\ldots]$} & {$[0.000]$} & {$[0.000]$} \\
t-value & $\{\ldots\}$ & $\{-11.208\}$ & $\{-24.278\}$ \\
\hline
\end{tabular}

Turning to short-run dynamics, Figure 2 presents impulse response functions of 1 EUR price increase shock of emission permits and coal to electricity price. We can see that the increase of emission permit price has a slower onset, but is more persistent than the resulting increase 
of coal price. The latter peaks rather quickly after three months and then fades away. However, since the underlying time series of the used data is quite short, the plotted $95 \%$ confidence intervals show that the margin of error is relatively large in both cases and any resulting conclusions should be then taken with due consideration.

Figure 2: Impulse response functions (model with 1 lag)

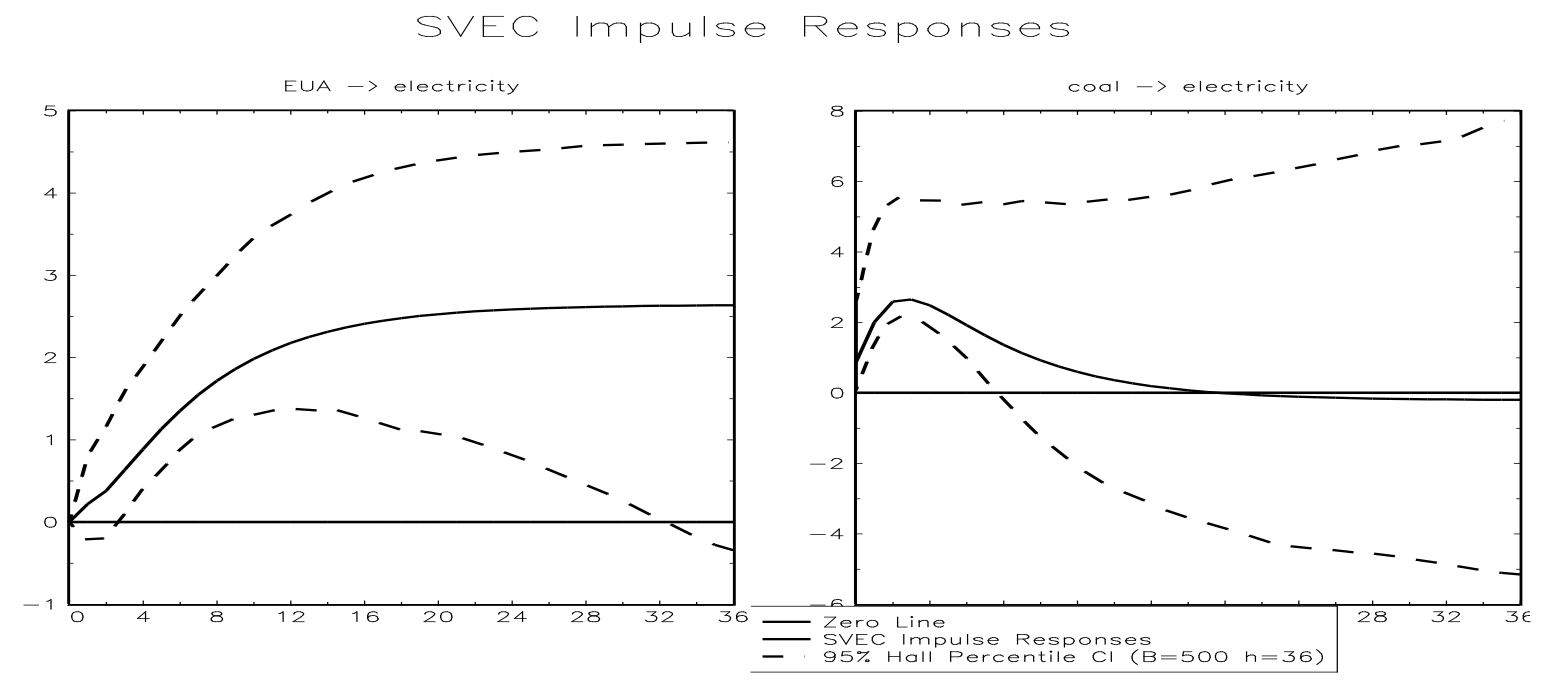

Figure 2: Impulse response functions (model with 2 lags)
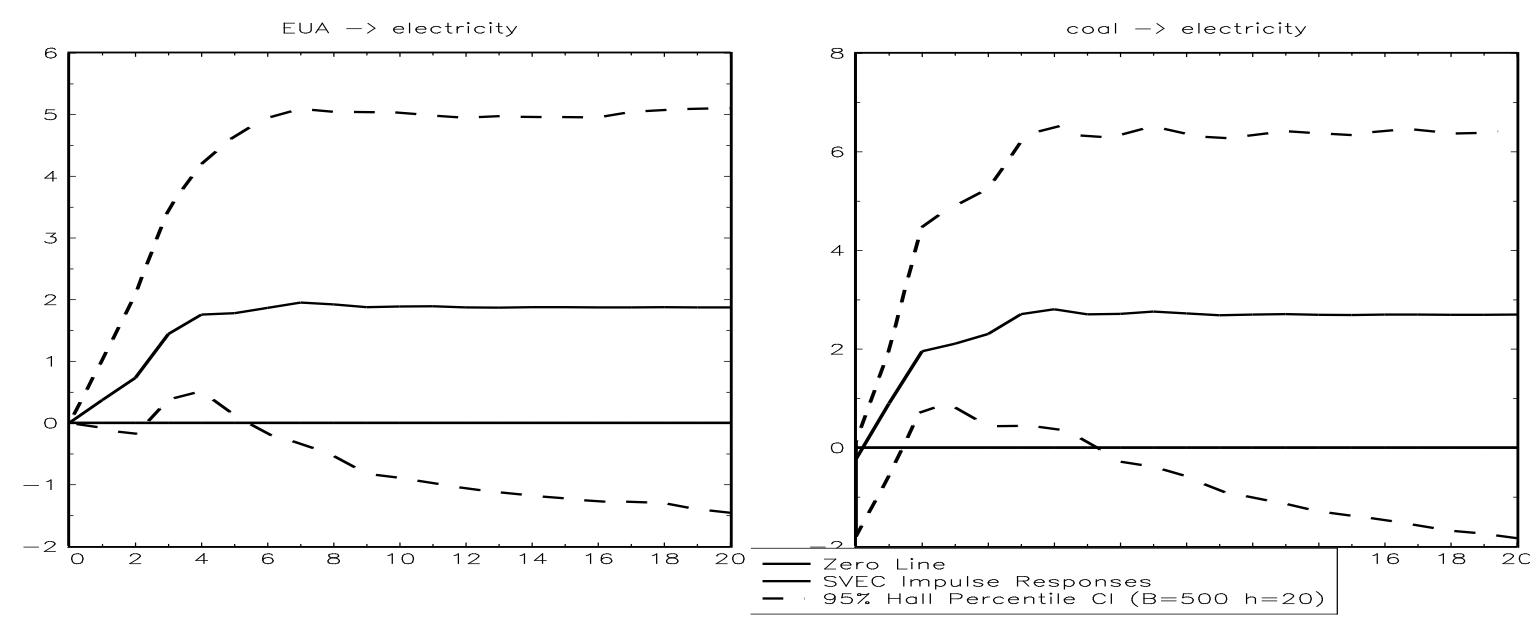

\subsection{Economic Interperation}

We used the structural cointegrated VAR model to demonstrate the relationship between electricity prices and EU ETS allowances scheme within conditions of Czech electric energy market. Model has confirmed importance of the EU ETS system introduction as a transparent, environmental and market based instrument. From a perspective of the EU climate change policy, the European Trading Scheme was meant as a main tool to introduce a system that enables the inclusion of externalities coming from burning the fossil fuels into the price of final output on the "polluter pays" principle. As we can read form the first results this might 
not have been fulfilled as the ETS has passed an increased costs burden from electricity producers to final electricity consumers i.e. according to a "consumer pays" principle.

At the same time the introduction of the ETS highlighted the issue of so called "carbon leakage" 5 . This finding holds true namely within the "new" EU Member States (based on the fact, that the industrial and power generation base of the Czech Republic very similar to other countries form the Central and Eastern Europe) were the above described transmission caused increased energy prices for a number of energy intensive industries. This slightly disconcerting fact might even double in future with the introduction of the third phase of the ETS when the allocation of allowances for free is going to be gradually replaced by allowances auctioning. We will have to wait till the European Commission gives us a final word on how many of them might be marked as endangered by "carbon leakage" and will be treated under a "softer" way of the ETS.

\section{Conclusion}

Following the final model outputs from long term view, we confirmed that emission allowance prices define the level to which energy price is attracted. Finally, based on this fact and pointing at the current imperfect allocation of emission allowances, major presumption is resulting from model output - a dependence of electricity prices on emission allowances will be stronger after a suppression of EA allocations and a commencement of $100 \%$ auctioning of EA within the EU ETS system.

\section{Literature:}

[1] BUNN, Derek W. a FEZZI, Carlo. Interaction of European Carbon Trading and Energy Prices. Note di Lavoro Series, Fondazione Eni Enrico Mattei, 2007.

[2] MCCOY, Daniel. How useful is Structural VAR analysis for Irish economics? Dublin: Technical Paper, Central Bank of Ireland, 1997.

[3] FELL, Harrison. EU-ETS and Nordic Electricity: A CVAR approach. Discussion paper, Resources for the Future, 2008.

[4] HAMILTON, James D. Time Series Analysis. Princeton: Princeton University Press, 1994.

[5] JESELIUS, Katarina. The cointegrated VAR model. New York: Oxford University Press, 2006.

[6] JOHANSEN, Soren. Estimation and hypothesis testing of cointegration vectors in Gaussian vector autoregressive models. Econometrica, vol. 59, n. 6, 1991, p 1551-1580.

[7] JOHANSEN, Soren. Likelihood-based inference in cointegrated vector autoregressive models. Oxford: Oxford University Press, 1996.

[8] SIMS, Christopher. Macroeconomics and reality. Econometrica, vol. 48, n. 1, 1980, p 148.

[9] BARKER, Terry a METZ, B. et al. Carbon leakage [online]. IPPC 2007 [2010-04-05]. Retrieved from http://www.ipcc.ch/publications_and_data/ar4/wg3/en/ch11s11-7-2.html.

\footnotetext{
${ }^{5}$ Carbon leakage is defined as the increase in $\mathrm{CO} 2$ emissions outside the countries taking domestic mitigation action divided by the reduction in the emissions of these countries (9).
} 


\section{Annex}

Table 2: Test statistics (model with $1 \mathrm{lag}$ )

\begin{tabular}{|lcc|}
\hline Johansen trace test & likelihood ratio & p-value \\
$\mathrm{r}=0$ & 44.54 & {$[0.0030]$} \\
$\mathrm{r}=1$ & 9.57 & {$[0.6860]$} \\
$\mathrm{r}=2$ & 2.87 & {$[0.6135]$} \\
& & \\
Portmanteau test (up to 10 lags) & adj. test statistics & $\mathrm{p}$-value \\
& 117.7909 & {$[0.0024]$} \\
& & \\
ARCH-LM test (up to 10 lags) & test statistics & $\mathrm{p}$-value \\
e1 & 9.0023 & {$[0.5319]$} \\
e2 & 9.1292 & {$[0.5199]$} \\
e3 & 7.2074 & {$[0.7057]$} \\
& & \\
Jarque-Bera test & test statistics & p-value \\
e1 & 2.9243 & {$[0.2317]$} \\
e2 & 0.0166 & {$[0.9917]$} \\
e3 & 0.0714 & {$[0.9649]$} \\
\hline
\end{tabular}

Table 2: Test statistics (model with 2 lags)

\begin{tabular}{|lcc|}
\hline Johansen trace test & likelihood ratio & p-value \\
$\mathrm{r}=0$ & 32.93 & {$[0.0852]$} \\
$\mathrm{r}=1$ & 16.68 & {$[0.1469]$} \\
$\mathrm{r}=2$ & 4.10 & {$[0.4096]$} \\
& & \\
Portmanteau test (up to 10 lags) & adj. test statistics & $\mathrm{p}$-value \\
& 117.7909 & {$[0.0024]$} \\
& & \\
ARCH-LM test (up to 10 lags) & test statistics & p-value \\
e1 & 9.0023 & {$[0.5319]$} \\
e2 & 9.1292 & {$[0.5199]$} \\
e3 & 7.2074 & {$[0.7057]$} \\
& & \\
Jarque-Bera test & test statistics & -value \\
e1 & 2.9243 & {$[0.2317]$} \\
e2 & 0.0166 & {$[0.9917]$} \\
e3 & 0.0714 & {$[0.9649]$} \\
\hline
\end{tabular}




\section{JEL O13, Q53, Q54, R15}

\section{Ing. Barbora Vondrušková}

Asistentka a doktorandka Katedra světové ekonomiky

Fakulta mezinárodních vztahů

Vysoká škola ekonomická

Nám. W. Churchila 4, 13067 Praha 3

Tel.: +420224095234

brvn@seznam.cz

Doc. Ing. Ingeborg Němcová, CSc.

Docentka Katedra světové ekonomiky

Fakulta mezinárodních vztahů

Vysoká škola ekonomická

Nám. W. Churchila 4, 13067 Praha 3

Tel.: +420 224095356

inge@vse.cz

\section{Ing. Jiří Horák, MBA}

Doktorand Katedra světové ekonomiky

Fakulta mezinárodních vztahů

Vysoká škola ekonomická

Nám. W. Churchila 4, 13067 Praha 3

Tel.: +420608620793

mr.jih@seznam.cz 